\title{
Factors Affecting the Development of Women Entrepreneurs on Economic Activity: Cross Sectional Data
}

\author{
GETINET GEZAHEGN GEBRE \\ Lecturer, Department of Economics, Bonga University, Ethiopia
}

\begin{abstract}
This study was examined factors affecting the development of women entrepreneurs on economic activity of Bonga Town of south west region which is the capital city of Kafa Zone and $449 \mathrm{~km}$ from Addis Ababa. The general objective of the study is to assess factors affecting the development of women entrepreneurs on economic activity of Bonga Town. The specific objective of the study is investigating the basic factors that affect women entrepreneurial development on economic activity. The data were examined by using Statistical Package for Social Science. The Primary data were collected from the sample study through questionnaires. The Secondary data were obtained from reviewing available materials. The study used descriptive method to describe and interpret factors affecting the development of women entrepreneurs on economic activity of Bonga Town. The Cross-sectional data were collected 50 sample respondents. According to the study, about $40 \%$ of women entrepreneurs in the town are affected by the challenges faced in fulfilling the necessary things and $60 \%$ are not affected by it. As a result, the researcher has suggested that training access and institutional support by government are basic solution.
\end{abstract}

Keywords: Women, Entrepreneurs, Economic Activity

DOI: $10.7176 / \mathrm{JESD} / 12-1-01$

Publication date: January $31^{\text {st }} 2021$

\section{INTRODUCTION}

Ability to effectively use entrepreneurship in poverty reduction general and alleviating the problems. Among women who are vulnerable for poverty in particular; in bringing meaningful economic and social transaction; in promoting and enhancing gender equality and women empowerment; and in certifying women's social mobility in the nation might require worth mentioning (Amha and Admassie, 2018). This study drawn that more than partial of all women entrepreneurs in Ethiopia often face gender related challenges related to establishing new businesses as well as operating or expanding existing businesses. Women entrepreneurship is progressively recognized as a significant driver of Economic growth, productivity, innovation and employment, and transforming ideas into economic opportunities is the key issue of entrepreneurship.

Historically, economic improvement has been significantly advanced by pragmatic people who are entrepreneurial and innovative, able to exploit opportunities and willing to take risks (Hisrich, 2015). The role of entrepreneurship and an entrepreneurial culture in Economic and social development has been undervalued. Conversely, it has become increasingly outward that entrepreneurship indeed contributes to economic development. Nevertheless, the significant numbers of enterprises were owned by men (ILO, 2016).

According to Aregash as mentioned in Esthetic and Zeleke (2008), 98\% of commercial firms in Ethiopia are micro and small Enterprises. This displays that Ethiopia is among those African countries that are acknowledged by human resource potential. When we come to Bonga town, it is one of the town in which many women are found (Holt, 2014).

In this context, entrepreneurship can be recorded as engine of growth for the private sectors. Which was neglected in the past in Ethiopia, it must be noted that, treating entrepreneurship is difficult in the country context because of data limitation. In any extent, the present's development objective of the country based on the creation of a robust private sector demands fastening entrepreneurship development which has the ability to breed entrepreneurs (Stevenson, 2015).

\section{Statement of the problem}

Entrepreneurship is the main vehicle of economic diversification higher living standard and increasing levels of self-reliance. This is supported by different empirical evidences. Gamachis (2007) and ILO (2009) stressed that entrepreneurs are surrounded by a number of challenges. This forces entrepreneurs not to contribute lot to the poverty reduction of the sub-city, region and the country as a whole.

Women entrepreneurs in poor nations suffer from gender discrimination in society and laws, small enterprise culture, inadequate support system for businesses and small markets and infrastructure. Mostly, women-owned businesses are focused in the low growth segment, face constraints such as reduced access to finance, shortage of business development services and business networks (Desta, 2010). This study is believed to fill the gaps by identifying specific factors that are responsible for resilience in MSEs operated by women entrepreneurs, and shade light on women specific differentials that affect their Performance.

Factors showing entrepreneurship by its nature is too vast. Because of this, the study emphasized on 
identifying the factors that affecting women's entrepreneurship and problems uncounted during the development entrepreneurship. Also with scarce resource available to investigate all angles of a given topic in a single study encompassing the idea and comments of all household, or women's living in the town is very much difficult. Hence the research focused on the specific factors that affect entrepreneurship development on economic activity of Bonga town.

This paper has organized by five chapters; the first chapter contains background, statement, objective, limitation, and scope. The second chapter deals with literature review of the study which includes theoretical and empirical review. The third chapter deals with methodology of the study which includes data types and sources, data collection method, sampling procedure, sampling techniques and methods of data analysis .The fourth chapter deals with data analysis and interpretation which includes the factors affecting the development of women entrepreneurs on economic activity of Bonga Town. Finally, chapter five deals with conclusion and recommendation.

\section{RELATED LITERATURE REVIEW}

\section{THERIOTICAL LITERATURE}

According to Ponstadt (2008) Entrepreneurship is the dynamic process of creating incremental wealth. This Wealth is created by individuals who assume the major risks in terms of equity, time and career commitments of providing values for some Product or service. The product or service may or may not be new or unique but value must be infused by the entrepreneur by securing and allocating the necessary skills and resources.

Furthermore, Entrepreneurship is the process of creating and building something of value from practically nothing. It contains the definition, creation and distribution of values and benefits to individuals, groups, organizations and society. Entrepreneurship is very hardly a get rich-quick suggestion; rather it is one of building long term value and durable cash flow streams (Timmons, 2009).

Entrepreneurship is the process of generating something new with value by devoting the necessary time and effort, assuming the accompanying financial and social dangers, and receipts the resulting rewards of monetary. (Hisrich, 2005).

Economically and enable them to contribute more to overall development whether they have difficult in small or medium scale production activities, or in the informal or formal sectors, women's entrepreneurial activities are not only a means for economic survival but also have positive social effects for the women themselves(UNDO, 2001).

In many societies women do not enjoy the same opportunities. Economy progress has been reached in opening doors to education and health protection for women but political and economic opportunities for female entrepreneurs have limited. Concerted efforts are needed to enable female entrepreneurs to make better economic choices and to transform their businesses into competitive enterprises, generating income and Employment through improved production (OECD, 1997).

\section{Empirical literature review}

Key factor that influence women entrepreneurship include attitude, environment and motivation. (Ekpe,Mat and Razak 2011).The push factor include unemployment, redundancy, recession, inadequate family income, dissatisfaction with being employed or the need to accommodate a work and home roles simultaneously. The pull factors are motivated by need for independence and need to succeed better than others as entrepreneurs. The critical pull factors in entrepreneurships include education, attitude and experience.

It is richly clear entrepreneurship is central for economic growth, productivity, innovation and employment, and many nations have made entrepreneurship explicit policy priority. Their policy focused in Entrepreneurial, economic development and performance and wealth creation. According to WB (2007), Hisrich (2005) and fox (2001), entrepreneurship has the following benefits. Entrepreneurs are their own bosses. There make the decisions. They select whom to do business with and what work they will do. Entrepreneurship offers a greater possibility of achieving significant financial rewards than working for someone else; It provides the ability to be involved in the total operations of the business, from concept to design and creation, form sales to business operations and customer response.

(UNECE, 2004) and (Mahbub, 2000) identified the factor that affect women entrepreneurs. Access to fiancé is key issue for women. Accessing credit particularly for starting an enterprise, is one to the major constraints faced by women entrepreneur women often have fewer opportunities than mentor gain access to credit for several reasons, including absence of collateral, an unwillingness to accept house hold assets as collateral and negative insights of female entrepreneurs by loan officers (Mahbub, 2000).

The ability top into new markets requires expertise, knowledge and contacts women batten lack access to training and experience in on how to participate in the market place and are therefore unable to market goods and services strategically. Thus women dawned sums are often unable to take on both the production and marketing of their goods. In addition, they have offend not been exposed to the international market, and therefore lack 
knowledge about what is internationally acceptable. The high cost of developing new business contracts and relationship in a new chantry or market is a big different obstacle for many SMES, in particular women owned business (UNECE, 2004).

Women have restricted access to vocational and technical training in Bonga town. In fact women on average have less access to education to education than men, and technical and vocational skill can only be developed on a strong foundation of basic primary and secondary education. Bonga Town is characterized by low enrollment among women in education, high dropout rates and poor quality of education. The table below shadows female literacy levels of percentage of mole literacy as well as average years of schooling of women and men, respectively (UNECE, 2004)

\section{METHODOLOGY}

\section{Type and Source of Data}

The data were obtained from both primary and secondary source. Primary data were obtained from sample study, structured and unstructured questionnaires. The researcher is obtained primary data through preparing and distributing questionnaire. The questionnaire contains both open and closed ended questions which was prepared and distributed to respondents. The data were collected from 50 sample respondents of women entrepreneurs of the Bonga town. Secondary data were obtained from reviewing available literature, books, and magazines, written document, both published and unpublished, different booklets and annual reports from the organization.

In Bonga town there are four kebeles. So the researcher would decide to select both of them for study and 100 women entrepreneur are found in these kebeles who are main target of the study. But due to time and a budget constraint the researcher select 50 samples from the 100 entrepreneurs. In order to select these sample respondents, random sampling technique used by applying the following formula.

$n=\quad \frac{N /}{1+N}(e) 2$

Where, $\quad \mathrm{n}=$ sample size

$$
\begin{aligned}
& \mathrm{N}=\text { Total population }(\mathrm{N}=100) \\
& \mathrm{e}=\text { sample error }(\mathrm{To} \text { take a } 10, \quad \text { degree level of significance }=0.1) \\
& \mathrm{n}=100 / 1+100(0.1) \\
& \mathrm{n}=100 / 2=\underline{\underline{00}}
\end{aligned}
$$

The data has been analyzed using descriptive tools such as percentage, mean, median, mode, max, min and etc. The researcher used tables, simple averages and proportions from the quantitative data collected from primary sources. The statistical package for social science (SPSS) version would be used to analyze the data obtained from primary source. The reason for using descriptive tool is to compare the different factors that affect the performance of women entrepreneurs on Economic activity.

\section{DATA ANALYSIS AND INTERPRETATION}

This part details about finding of the study and discussing of on the basis of data gathered by primary sources. The response of women entrepreneur is also interpreted by qualitative or descriptions. The response and analyses is presented as follows table.

\section{Table: Concerning Awareness of Respondents and percentages}

\begin{tabular}{ll|l|l} 
No & $\begin{array}{l}\text { Number of respondents and percentage } \\
\text { Awareness status }\end{array}$ & Number of respondent & Percentage \\
\hline & $\begin{array}{l}\text { Number of women entrepreneurs who have lacks } \\
\text { experience }\end{array}$ & - & - \\
2 & Extremely high problem & 4 & 8 \\
3 & High problem & 22 & 44 \\
4 & Less problem & 6 & 12 \\
5 & Neutral & 18 & 36 \\
\hline
\end{tabular}

Own source; 2019

According to the table, $44 \%$ of them have lack of experience as high problem. The researcher understands that a woman in Bonga town is affected by technological application problems taking their lack of experience. But $36 \%$ of them are found as neutral .The sample indicates that more than $44 \%$ of women entrepreneurs in Bonga are with a big problem of experience or awareness on how they can develop their trading activity, therefore according to table, most of or more than half women entrepreneurs in Bonga are need of training about entrepreneurship.

The researcher deal as the problems that resulted from lack of knowledge about the rules and services of lending obligation and is showed women entrepreneurship the problems that resulted above form the sample table 
is too minimal. Because the percentage of problems that affects women entrepreneurship in its extreme and high is amounted to $15 \%$ and this is indicated even the women entrepreneurs in the town of Bonga has knowledge about rules and service about lending obligation, they do not lend and flow the rules and services that made effective and efficient entrepreneurship. Hence since $80 \%$ of the women entrepreneurs are less proved by the knowledge of the rules and services of the obligation lending there is on extreme problem with regard to the knowledge of the rules and services of the obligation of lending.

Women entrepreneurs are also affected by lack of information for about $28 \%$ but this percentage is not affected these women in its great sever manner or has very minimal problem since the amount of less problem is about $72 \%$. Therefore, even these women entrepreneur have less aware or experience about the entrepreneurship they have sufficient knowledge and information about the current work condition.

Table: Concerning shortage of money to start their Business

\begin{tabular}{llll}
\hline $\begin{array}{l}\text { Number of respondent and percentage } \\
\text { No }\end{array}$ & No of respondent & Percentage \\
\hline & $\begin{array}{l}\text { Number of women entrepreneur who are affected by lack of } \\
\text { money to start their business }\end{array}$ & & \\
\hline a. $\quad$ Extremely high problem & 14 & 28 \\
b. $\quad$ high problem & 16 & 32 \\
\hline & & 16 & 32 \\
\hline c. $\quad$ Less problem & Neutral & 4 & 8 \\
\hline
\end{tabular}

Source: own survey 2019

The main objective is to access the problems that can be resulted to women entrepreneurs in Bonga town due to lack of money to start their business. According to this table, those women are affected by lack of money which is about $60 \%$, the researcher considers the women entrepreneurs in Bonga town are unable to start their business due to lack of money, Meaning these women entrepreneurs are in need of government support. So the financial capacity problem of women entrepreneurs in Bonga is big obstacle for involving in entrepreneurship activities Table: Concerning the Attitude of Society towards women Entrepreneurs

\begin{tabular}{|c|c|c|c|}
\hline \multirow[t]{2}{*}{ No } & \multirow[t]{2}{*}{ Problems of women entrepreneur } & \multicolumn{2}{|c|}{ Number of respondents and percentage } \\
\hline & & Number of respondent & Percentage \\
\hline \multirow[t]{7}{*}{1} & Attitude of society toward women entrepreneurship & & \\
\hline & & - & - \\
\hline & Extremely high problem & 10 & 20 \\
\hline & High problem & 15 & 30 \\
\hline & Less problem & 20 & 40 \\
\hline & Neutral & 5 & 10 \\
\hline & Total & 50 & 100 \\
\hline \multirow[t]{6}{*}{2} & Cultural influence of the community & & \\
\hline & Extremely high problem & 0 & 0 \\
\hline & High problem & 10 & 20 \\
\hline & Less problem & 12 & 24 \\
\hline & Neutral & 28 & 56 \\
\hline & Total & 50 & 100 \\
\hline \multirow[t]{6}{*}{3} & $\begin{array}{l}\text { Number of women who are affected by non -acceptability } \\
\text { of their business by the society }\end{array}$ & & \\
\hline & Extremely high problem & 8 & 16 \\
\hline & High problem & 8 & 16 \\
\hline & Less problem & 22 & 44 \\
\hline & Neutral & 12 & 24 \\
\hline & Total & 50 & 100 \\
\hline \multirow[t]{6}{*}{4} & $\begin{array}{l}\text { Number of women entrepreneurs that are affected by } \\
\text { afraid related problem }\end{array}$ & & \\
\hline & Extremely high problem & 10 & 20 \\
\hline & High problem & 20 & 40 \\
\hline & Less problem & 12 & 24 \\
\hline & Neural & 8 & 16 \\
\hline & Total & 50 & 100 \\
\hline
\end{tabular}

Source; own survey 2019 
The main objective is concerning the problem of women entrepreneurship with regard to social attitude, cultural influence, non- acceptability of the business of women entrepreneurship by the society and related problem.

According to the study, $50 \%$ of the sample women entrepreneurs are endangered by social altitudes and the remaining 50\% are not. The researcher considers that social attitude is one of the factors for the problems of women entrepreneurship in Bonga town who are working in different creative works. The researcher understands that cultural influence has a little impact on the development of women entrepreneurship, since $80 \%$ of women entrepreneurs in the town of Bonga is not affected negatively by the cultural influence of the community even $20 \%$ are endangered by this problem.

The researcher deals with the problems of women entrepreneurship that can be resulted to women entrepreneurs due to the non-acceptability of the business created women entrepreneurship by the society according to the sample, the amount of non-acceptability of the business by the society somewhat small which is $32 \%$ which is less in cooperation to $68 \%$ is acceptability by the society. The effect of non-acceptance to the society by the society to the business created by the women entrepreneurs is minimal.

The researcher is dealing with women entrepreneurship problems related to challenges coming from fulfilling the necessary thing. About $40 \%$ of women entrepreneurs in the town of Bonga are affected by the challenges faced in fulfilling the necessary thing and $60 \%$ are not affected by it. So the challenges faced unfulfilling the necessary thing has no a great damage on the women entrepreneurs in Bonga town.

Generally; from above table, the researcher conclude that although the problem above affect women entrepreneur in this town is weather in amount of great or not they have their own problem on these women entrepreneur.

\section{CONCLUSION AND RECOMMENDATION}

\section{Conclusions}

Women entrepreneurs in the town of Bonga are young who are mostly married and single and in the way of educational level they can write and read that helps them to be effective and efficient entrepreneurs. The women entrepreneurship is generally full of problems. The main problem for women entrepreneurship development in the town are such as lack of awareness about entrepreneurship, lack of knowledge about the rules and services of lending obligations of women entrepreneurship and lack of information about the business.

The regional government of SNNPR has played a big role in encouraging women entrepreneurship through providing the possible opportunities like providing support to develop their interest rate, controlling women entrepreneurs from unfair competition, providing the required technological facilities, avoiding sex deference responsibility and allowance of credit services. In addition to the problems above social attitude, cultural influence, the non-acceptability of women's business though creativity, afraid of women in entrepreneurship are also the obstacle for the development of women entrepreneurship.

Problems for women entrepreneurship development also include lack of raw materials, the legal and political obligation given by the government and the challenges resulting UN fulfilling the necessary inputs. In conclusion, the above factors are the main problems of women entrepreneurship development in Bonga town.

\section{Recommendations}

The primary focus and purpose of women entrepreneurship in Bonga town is to alleviate poverty and make women entrepreneurship more encourage through fulfilling the necessary facilities required to them. The study related that the factors, which can affect women entrepreneurship, can be lack of awareness, backwards attitude of the society towards women entrepreneurship and other related problems.

Nevertheless, the results of the different evidence are helpful for make following recommendations; Federal or regional government should create awareness to women's of the town about entrepreneurship by training on varies issue and facilitate for them what they are need, the arrangement of tax collection is very important for these women that mean it should be proportional and the government should allow the accessibility women entrepreneurs by giving special treatment, the unit competitive market is also very important for these women so if possible it is good if government control it, the teaching women should play a big role in changing the attitude of the society, avoiding the problems resulted from them due to cultural influence and a triad related problems, the government should help women entrepreneurship by providing necessarily legal and political obligations and giving right for women entrepreneurs the same as men. In generally women should avoid the feeling dependency on all activities of their life especially on entrepreneurship.

\section{REFERENCE}

Eshetu, B. and Zeleke W. (2008) women entrepreneurship in micro, small and medium enterprises: The Agricultural Growth before and After Reform, Agri.Econ, Vol.78, No.2, pp.331-338.

Fiday or para (2002) entrepreneurship case and text Enugu, Nigeria: A Study of Farmers Within and Outside the Sasakawa-Global 2000 Project. Agricultural Economics, Vol. 19, No.3, pp.341-348. 
Hidiya Mohamed (1998) sharing experiences success stories of women entrepreneurs. World Bank Environment Department Paper 91,World Bank, USA.

Hailai G, (2003) entrepreneurship and small business management, Ethio - central printings press Ethiopia

Holt (2014) entrepreneurship new venture creations, New Delhi, India.

ILO (2008) women entrepreneurs in Kenya factor affecting women entrepreneur) in micro and small entrepreneur in Kenya. Geneva. International labor organization.

Mohbub, U.H (2000) human development Center, human development in south- Asia. The gender question (oxford university press).

OECD (1997) entrepreneurship and SmEs in transitional economics the vise grade conference, OECD proceedings, and paresis. Applied Econometrics, Vol. 29, pp.1217-1226:

Stevenson (2005) entrepreneurship and small business management Ethic-central printing press. Journal of the Society for International Development, No. 1-4, p.37.

UNECE (2004) women's self-employment and entrepreneurship in the ECE region, background paper prepared by the secreatriate for the regional sympsiumon mainstreaming gender in to economic policies Geneva, 2830 January 2004. 